PF 2019 (LXXIII): 467-479

\author{
ALENA MACUROVÁ \\ NAĎA HYNKOVÁ DINGOVÁ \\ Ústav jazyků a komunikace neslyšících \\ Filozofická fakulta, Univerzita Karlova \\ nám. Jana Palacha 1/2, 11638 Praha 1 \\ tel. (+420) 221619210 \\ e-mail: alena.macurova@ff.cuni.cz \\ e-mail: nada.dingova@ff.cuni.cz
}

\title{
REFLEXE JAZYKA, ŘEČI A KOMUNIKACE V ČESKÉM ZNAKOVÉM JAZYCE
}

KLÍČOVÁ SLOVA: hluchota, neslyšící člověk a jeho jazyk/y, ikoničnost, motivace, kódování / mapování mentálních představ

SŁOWA KLUCZOWE: głuchota, człowiek niesłyszący i jego język(i), ikoniczność, kodowanie / mapowanie wyobrażeń mentalnych

KEYWORDS: deafness, the Deaf and his language/s, iconicity, motivation, coding / mapping of mental images

\section{THE REFLEXION OF LANGUAGE, SPEECH AND COMMUNICATION IN CZECH SIGN LANGUAGE}

\begin{abstract}
As cognitive or cognitive-cultural linguistics demostrates „to be a human being”, "to understand” (oneself, the others, the world) and „to understand each other” is inseparably bound to the human ability to use language/speech; through language/ speech the human being becomes rooted in the culture and the world, interprets it and assigns meaning to all of it. The same applies to human beings that cannot hear, to the deaf. In our study, we examine selected language, speech and communication issues concerning the specific aspects of the linguistic and communication situation of the Czech deaf, especially with regard to the iconicity of their natural language, i.e. Czech Sign Language. Our reflections focus mainly on its lexical or lexical-semantic level, particularly on its so-called visual symbolism (the projection of iconicity into phonology). Based on our observations, we try to describe „the linguistic worldview of (Czech) sign language” and perhaps even of the communication mediated by this language.
\end{abstract}


ABSTRAKT: Reflexe jazyka, řeči a komunikace v českém znakovém jazyce. Jak dokládá kognitivně kulturní lingvistika, „být člověk”, „rozumět” (sobě, jiným, světu) a „rozumět si” je nedílně spjaté s lidskou schopností jazyka /řeči, že; skrze jazyk/řeč člověk vrůstá do kultury/do světa - a tento svět i sebe sama interpretuje, resp. přiděluje mu smysl. To platí i pro člověka, který neslyší. Vybrané reflexe jazyka, řeči a komunikace jsou zvažovány se zřetelem k specifikám jazykové a komunikační situace českých neslyšících, zvl. se zřetelem k ikoničnosti jejich přirozeného jazyka - českého znakového jazyka; úvahy se přitom soustředí především na jeho lexikální, resp. lexikálně sémantickou stránku, a to zvl. na tzv. vizuální symbolismus (průmět ikoničnosti do fonologie). V opoře o to bude v náznacích nastíněn ,jazykový obraz (českého) znakového jazyka” a snad i „obraz komunikace" tímto jazykem vedené.

Následující úvahy nabídnou zřejmě více otázek $\mathrm{k}$ diskusi než jednoznačných odpovědí. Dáno je to především tím, že (1) lingvistika českého znakového jazyka je disciplína relativně mladá - a víceméně v počátcích je prrístup, jenž by v jejím rámci rozvíjel poznatky lingvistiky kognitivně kulturní; (2) zvažovaná problematika je značně široká (viz i víceznačnost titulu): zahrnuje jak reflexi jazyka, řeči/ komunikace v jazyce samém - zvl. ve formě znaků českého znakového jazyka, tak reflexi ukotvenou $\mathrm{v}$ řeči/ komunikaci, v projevech českých neslyšících realizovaných v českém znakovém jazyce (a nevyhnutelně také v dalším „povinném”1 jazyce, smyslově neslyšícím přístupném, v psané češtině); (3) reflexe jazyka, řeči/ komunikace v českém znakovém jazyce bude nahlížena převážně zvnějšku, úhlem pohledu slyšícího člověka, „cizince”. To může být - vedle řady nevýhod, které to s sebou nese - i výhodou, vezme-li se za jisté, že „národno-kultúrnu špecifiku vidí predovšetkým cudzinec” (Lotman 1994, s. 12).

Východiskem předložených úvah je přesvědčení primárně ukotvené v kognitivní, resp. kognitivně kulturní lingvistice: že „být člověk”, „rozumět” (sobě, jiným, světu) a „rozumět si” je nedílně spjaté s lidskou schopností jazyka/řeči, že skrze jazyk/řeč člověk vrůstá do kultury, do světa - a tento svět, sebe sama i svůj jazyk a svou komunikaci interpretuje, přiděluje jim smysl. To platí i pro člověka, který neslyší. I neslyšícího člověka je možné označit herderovským Homo loquens, jako živoucí bytost nadanou, resp. definovanou užíváním jazyka, bytost, která do světa vstupuje se schopností jazyka, resp. je vybavena vrozenými mentálními předpoklady pro jazyk. To, zda neslyšící člověk jazyka - a jakého jazyka - skutečně nabude, a čím vším to je komplikované, zde lze naznačit jen krátce. Do hry vstupuje způsob osvojování prvního jazyka (zvl. dětmi narozenými do slyšící rodiny, které mluvenou češtinu svých rodičů neslyšící a k českému znakovému

1 Povinném v tom smyslu, že gramotnost musí neslyšící člověk nabývat v jazyce většinovém, v ČR v češtině: žádný znakový jazyk nemá psanou podobu. 
jazyku obvykle nemají přístup), školská praxe (jež ještě stále mnohdy namísto gramotnosti v psané češtině směřuje k oralisty preferovanému „mluvení”), jazyková politika (v oblasti vzdělávání neslyšících např. volba jazyka vzdělávání), také (ne vždy kladné) postoje slyšících Čechů (zvl. vzdělavatelů neslyšících) k českému znakovému jazyku a ne v poslední řadě postoje neslyšících Čechů k jazyku / jazykům, jež mají - teoreticky - k dispozici; tyto postoje (resp. jejich více či méně explicitní reflexe) zřetelně konstituují opozici „náš” X „jejich” jazyk (český znakový jazyk X čeština), srov. v psané češtině např.

- DEAFS PATRI ZNAKOVY JAZYK a ne CESKY JAZYK.

- ... Neslysici patri ZJ a kultura, a budete MLC a tecka. Ja respektuju Slysici patri CJ a kultura.

- Když deaf neumí ZJ, to je stejna jako když slysici neumi CJ to je primitiv. Když deaf umi ZJ, to je stejne jako když slysici umi CJ, TO JE NARODNI JAZYK.

- Jsi Neslysici, a vis co to je Lingvista??? Slysici ma vlastní CJ a vi co je pravidla lingvista. a co ty vis LINGVISTA ZJ? LIGNVISTA ZJ je plnohodnoty jazyk, a takove souvsil CJ neexistuje. Deaf ma vlastní matersky ZJ.

- Deaf spravne hodi vychova první jazyk co matersky jazyk je ZJ, pak druhy cesky psani jazyk - ... akdyz nevis informace tak mlc ze on te dava info a klid!!!!ne proti kvůli tomu cesky jazyk pro me je největší pitomec!!!!! jasny?3 (Šebková 2008).

Nejen v kontextu takových postojů českých neslyšících je na místě vybrané reflexe jazyka, řeči/komunikace $\mathrm{v}$ českém znakovém jazyce (v jeho systému i v promluvách v něm - a v češtině psané českými neslyšícími - realizovaných) zvažovat v různých souvislostech, přinejmenším: (1) v souvislosti se specifičností jazykové a komunikační situace českých neslyšících, s jejich bytím ve dvou jazycích (v přirozeném jazyce neslyšícího Čecha, českém znakovém jazyce, a v psané češtině jako jazyce gramotnosti), ve dvou kulturách, možná (Johnston 1996) ve dvou světech (někdy „mezi” dvěma jazyky, dvěma kulturami, dvěma světy - ani v tom či onom plnohodnotně); (2) v souvislosti se specifickou smyslovou zkušeností neslyšícího člověka; (3) v souvislosti se specifickými rysy znakového jazyka, s jeho „jinakostî", odlišností od většinového jazyka mluveného: znakový jazyk je vizuálně motorický jazyk bez psané podoby, který je charakterizován zvl. dvojími - manuálními a nemanuálními - nosiči významu, existencí v prostoru, s tím související simultánností - a ne v poslední řadě ikoničností, resp. tendencí $\mathrm{k}$ ikonické reprezentaci. Ikoničnost se ve znakových jazycích uplatňuje v podstatně větší míře než v jazycích mluvených: vizuální, v prostoru ukotvené jazyky

2 Obdobně v českém znakovém jazyce, aktuálně např. v diskusi o kochleárních implantátech na https://www.facebook.com/groups/Z\%C3\%A1bava-pro-nesly\%C5\%A1\%C3\%ADc\%C3\%AD-v -\%C4\%8CR-390327587816322/.

3 Zde i níže jsou české texty psané českými neslyšícími citovány tak, jak byly zveřejněny. 
jsou disponovány ${ }^{4}$ výrazněji než jazyky mluvené $\mathrm{k}$ tomu, aby aspekty vnějšího (časoprostorově organizovaného) světa, resp. lidské, vizuální a (časo)prostorové zkušenosti s tímto světem kódovaly/mapovaly „nápodobou”, ikonicky.

Otázka pak je, zda (a příp. do jaké míry) je s jinakostí jazyka svázána jinaká povaha jeho reflexe, popř. jinaká povaha reflexe řeči/komunikace v něm vedené. V základě nikoliv: I znakové jazyky, také český, exponují při reflexi jazyka, řeči/komunikace (stejně jako při kódování/mapování „světa” vůbec, srov. Wilcox 2000; Taub 2001) smysly a zkušenost, resp. lidskou tělesnou/smyslovou zkušenost. Smyslová zkušenost je ovšem u člověka, který neslyšící, v důsledku absence jednoho za smyslů, sluchu, jiná, resp. - z hlediska většiny - svým způsobem omezená: zvukové aspekty světa jsou pro něj smyslově nevnímatelné. I proto se, svým způsobem „kompenzačně, ve znakovém jazyce ${ }^{5}$ akcentuje vizuální vnímání světa, jeho aspekty vnímatelné zrakem. Jejich ikonická „nápodoba” se tak v lexikální rovině znakových jazyků vyjevuje přímo, zvl. ve formě vizuálně motivovaných znaků: forma přinejmenším části $\mathrm{z}$ nich poukazuje $\mathrm{k}$ jejich motivaci - a v souvislosti s tím také $\mathrm{k}$ jejich významu ${ }^{6}$. Vizuálně motivované znaky, charakterizované výraznou motivační linkou mezi konceptem a lingvistickou formou, pak ikonicky kódují/mapují mentální představy různého druhu - včetně jazyka, řeči/ komunikace.

Které prostřed $\mathrm{ky}^{7}$ českého znakového jazyka jsou pro takové ikonické kódování/mapování jazyka, řeči/komunikace, resp. - na nižší rovině zobecnění - pro jejich reflexi podstatné? Na základě excerpce znaků spojených s významovým okruhem jazyk, řeč/komunikace (ze Slovníku znakové řeči 1988 a V̌̌eobecného slovníku českého znakového jazyka 2002, 2004) lze předběžně říci, že v první řadě (nelze zatím rozhodnout, zda pouze) to jsou konstitutivní elementy znaku srovnatelné s fonémy ${ }^{8}$, tj. místo artikulace, tvar ruky a pohyb; v symetrických znacích artikulovaných dvěma rukama pak ještě vzájemná poloha rukou. $\mathrm{V}$ některých případech několik konstitutivní elementů, simultánně artikulovaných,

4 Srov. k tomu Fischer 2001, s. 187: „Sign languages exploit ikonicity because they can”.

5 A šířeji vzato v kultuře neslyšících: srov. např. tvorbu skupiny neslyšících umělců De'VIA (Deaf View/Image Art), do níž se vizuální způsob vnímání světa promítá (podrobně www.deafart.org).

6 Není přitom podstatné, zda motivátorem jsou vizuální charakteristiky vnějšího světa v širokém slova smyslu (a jde o motivaci percepční, např. ROHLÍK, nebo motorickou, např. JÍST, KLADIVO), anebo, bráno úže, je motivátorem (vizuálně vnímatelná) podoba psaného slova / části slova většinového jazyka (např. městská část PROSEK jako PROSIT). Znaky českého znakového jazyka jsou zde i níže v souladu s územ obvyklým v lingvistice znakových jazyků zapisovány velkými písmeny.

7 V centru zájmu zde stojí prostředky manuální, nemanuální prostředky (tvary a pohyby obličejových svalů, hlavy a horní části trupu) zůstávají stranou.

8 Označované jsou, $v$ různých teoretických rámcích, také jako aspekty nebo parametry. 


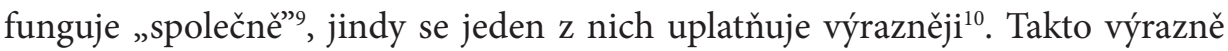
uplatněným konstitutivním elementem znaků reflektujících jazyk, řeč/komunikaci je jedno místo artikulace, totiž ústa ${ }^{11}$ (srov. např. znaky jako ŘíCT, PTÁT SE, OKŘIKNOUT, INFORMOVAT).

Ve znacích s místem artikulace ústa se výrazně uplatňuje tzv. vizuální symbolismus $^{12}$, vztah mezi „viditelnými” konstitutivními elementy znaku (tvar ruky, místo artikulace, pohyb) a významem: sdílenost (nějakého) konstitutivního elementu znaku zakládá sdílenost významu (srov. např. Frishberg-Gough 1973; Klima - Bellugi 1979; Woll 1983; Wilbur 1990) ${ }^{13}$.

Ústa se jako konstitutivní element samozřejmě uplatňují ve znacích různých významových okruhů, resp. v souvislosti s kódováním/mapováním lidské zkušenosti různého druhu, různá je i vizuální motivace př́slušných znaků (mnohdy se přitom uplatňuje „viditelné” konceptuální schéma TĚLO JAKO NÁDOBA, srov. Vaňková 2007, Pokorná 2017). Z významových okruhů spojených s tímto místem artikulace jen namátkou jmenujme např. potravu a s ní spojenou chut' (např. JÍST, PÍT, POLKNOUT, SLADKÝ, HOŘKÝ) nebo akce, v nichž se ústa angažují (např. FOUKAT, PLIVAT); ústa jsou v českém znakovém jazyce využita i jako motivátor (např. ČERVENÝ, RAJČE, ČERVENEC).

Ne nevýznamná část znaků s místem artikulace ústa ovšem reflektuje jazyk, řeč/komunikaci. Ale: jaký jazyk, resp. řeč/komunikaci v jakém jazyce tyto znaky reflektují? Některé, např. MLUVIT (obr. 1) nebo ODEZÍRAT jednoznačně komunikaci v jazyce mluveném (jeho produkci a specifickou, vizuální, recepci); k takové komunikaci se vztahují i znaky reflektující zvukové a foneticky artikulační parametry mluvené řeči (např. ŠEPTAT, MUMLAT). Ale jaký jazyk, resp. komunikaci v jakém jazyce reflektují znaky jako PTÁT SE (obr. 2), ODPOVÍDAT, LHÁT, MLUVIT PRAVDU (obr. 3)? Očividně také jazyk, řeč/komunikaci vázanou na způsob většinový, na „komunikaci ústy” (odkud vychází artikulovaný

9 Tak je tomu např. ve dvouručních symetrických znacích, v nichž dvě ruce reflektují interagující osoby, jejich pozice v neutrálním znakovacím prostoru a jejich pohyb pak bud’to (rukama vedle sebe a alternativním pohybem) vzájemnost, „výměnu” (např. KOMUNIKACE, DISKUTOVAT), nebo (rukama s dlaněmi orientovanými proti sobě a pohybem k sobě) střet (HÁDAT SE). K ikoničnosti dvouručních znaků srov. Lepic et. al. 2016, k jejich metaforické povaze srov. Šionchová 2007.

10 V souvislosti s metaforami srov. typ „single parameter metaphor” (Taub 2001, s. 114).

11 V samém znaku ÚSTA se uplatňuje ten princip kódování mentálních představ do jazykové formy, který bývá (Taub 2001, s. 67) označován jako přímá deixe (objekty a lidé/hmotné entity aktuálně přítomné během znakování jsou v procesu komunikace reprezentovány samy sebou).

12 Srovnatelnost s tzv. zvukovým symbolismem (např. Fónagy 1963, Zima 1961, Jílek 1967) je nasnadě: i v souvislosti s mluvenými jazyky se má zato, že některé prvky neznakové povahy (zvukové rysy) se potenciálně sémantizují, podílejí se na konstituci významu.

13 Tak např. místo artikulace hrud’ kóduje/mapuje emoce, hlava kognitivní procesy, tvar ruky V zase vidění, hledění. 
zvuk, Vaňková 2007) - a to přesto, že se neslyšící Češi ptají, odpovídají, lžou nebo mluví pravdu v jazyce jiném, v českém znakovém jazyce. Tato skutečnost kontrastuje s tím, jak výrazně čeští neslyšící reflektují opozici náš X jejich jazyk (viz výše), resp. - na vyšší rovině zobecnění - opozici „my” X „oni”14.

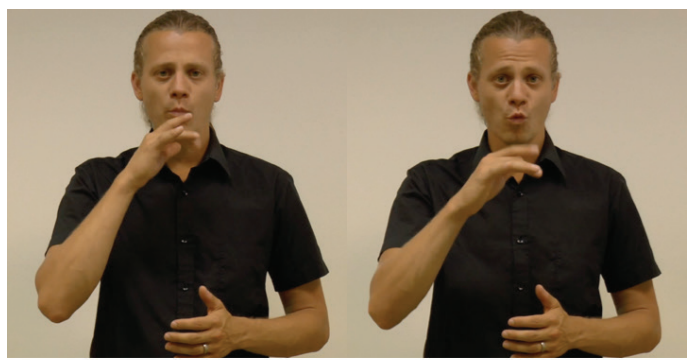

Obr. 1 MLUVIT (autor: Michal Brhel, Nad’a Hynková Dingová)

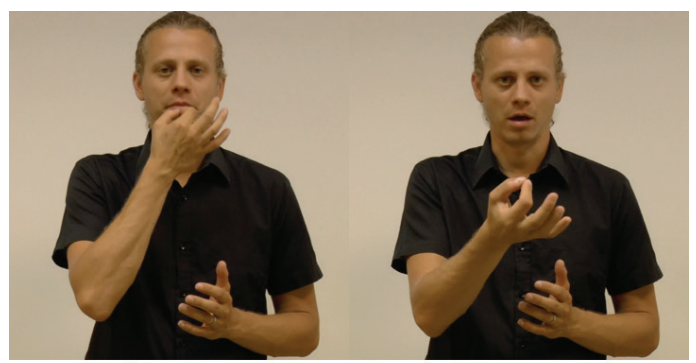

Obr. 2 PTÁT SE (autor: Michal Brhel, Nad’a Hynková Dingová)

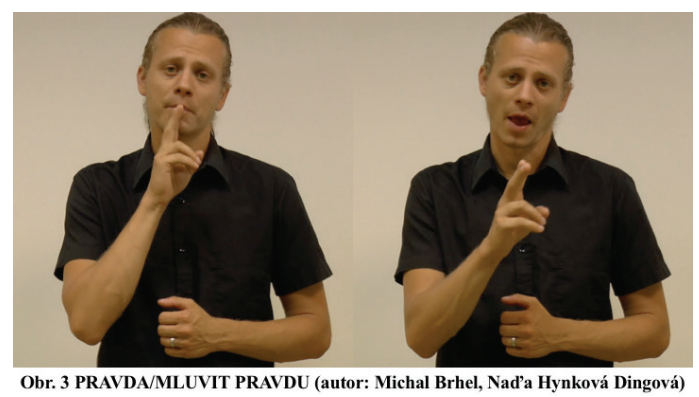

Není náhodou, že takový rozpor byl - v souvislosti s americkým znakovým jazykem - tematizován. Cory McMahon ${ }^{15}$, tlumočník amerického znakového jazyka, spojil (2016) znaky s místem artikulace ústa s ovlivňováním znakového jazyka většinovou, o zvuk opřenou kulturou a mluveným jazykem slyšící

14 Zřejmá je přitom souvislost mezi vymezováním „vlastní” skupiny, mezi identifikací (mj. i sdíleným jazykem) s touto skupinou a hledáním, utvrzováním identity neslyšícího člověka.

15 S jeho názory jsem se měli možnost seznámit až poté, co jsme své téma formulovali. 
populace; americké komunitě neslyšících doporučil jejich vědomé nahrazování znaky artikulovanými v neutrálním znakovacím prostoru, tj. znaky, které dle jeho názoru více korespondují s kulturou neslyšících a s povahou jejich jazyka ( $v$ americkém znakovém jazyce např. znaky VYPRAVOVAT, SDĚLIT, INFORMOVAT, VYJÁDŘIT).

Znaky, které odpovídají McMahonovům „požadavkům”, samozřejmě existují i v českém znakovém jazyce. Vedle těch dvouručních znaků artikulovaných v neutrálním znakovacím prostoru, o nichž už byla řeč (srov. zde pozn. 9), jim vyhovuje např. (také dvouruční) znak VYPRAVOVAT, který dost možná pokrývá oblast komunikace jak v mluveném, tak ve znakovém jazyce a reflektuje tak existenci neslyšícího člověka $\mathrm{v}$ obou ${ }^{16}$. Jiným př́kladem znaků respektujících kulturu neslyšících a zpo̊sob produkce a recepce znakového jazyka jsou znaky odpovídající českému pomluva, drb ${ }^{17}$.

Ty jsou - i vzhledem k úloze, kterou hrají pomluvy, resp. drby v komunitě českých neslyšících (viz níže) - zajímavé mj. počtem svých lexikálních variant. Dvě z nich POMLUVA1 a POMLUVA2 (obě artikulované mimo ústa) svou formou reflektují daný projev jazyka/akt řeči, resp. žánr v podstatě „protikladně”, nesouce negativní X pozitivní konotace.

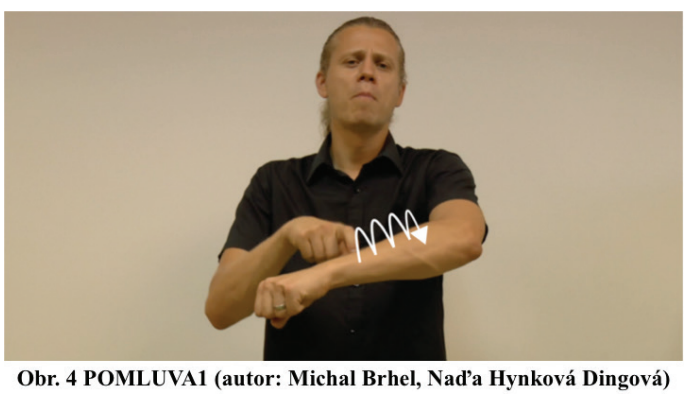

Znak POMLUVA1 (obr. 4), asymetrický dvouruční znak artikulovaný na předloktí pasivní ruky, vstupuje (místem artikulace a směrem pohybu) do vztahu se znakem KOUSNOUT - a do popředí tak primárně vystupuje ten významový rys pomluvy, který se spojuje se zraňujícím, „dál posílaným” (srov. opakovaný pohyb) negativním hodnocením nepřítomného člověka: podáním nepravdivé, neověřené, zkreslené informace má být tento člověk poškozen („kousnut”), jeho pozitivní obraz v komunitě má být narušen, posunut k obrazu negativnímu

16 Srov. v češtině psané českými neslyšícími „vypravovat” X „vypravovat rukama”: „Ve škole na H. jsem smutná, protože si se mnou nikdo nevypravuje”; „Nespokojená ve škole, protože já jsem sama a vůbec vypravuje mně a jsem byla smutná” X „Jsem málo zprávu nezlobí aby lepší ráda viděla vypraví ruka”.

17 K rozlišení v české kultuře a češtině srov. Hoffmannová 1996, Vaňková 2008; v českém znakovém jazyce (v kultuře českých neslyšících) tyto žánry rozlišeny nejsou. 
(k tomuto rysu pomluvy podrobně Vaňková 2008). Srov. i reflexi v českém znakovém jazyce:

Myslím, že to taky bude souviset s tím, že neslyšící obecně milují negativní věci. [...] to, co se komu kdy stalo, jaké problémy kdo má, kdo o co přišel, to si neslyšící nenechají utéct. Tyhle zprávy v nich vyvolávají př́ímo blažený pocit. [...] drby mají opravdu někoho ponížit, poškodit, mají někomu ublí̌zit, a ještě jsou určené $k$ šírení dál. Navíc to nemusí být často pravdivé, jsou to často zamlžené informace, polopravdy nebo dokonce úplné nepravdy nebo výmysly, ke kterým se ještě vrší další výmysly ${ }^{18}$.

Jako negativní se znak POMLUVA1 jeví i v (lingvisticky poučené) úvaze dalšího neslyšícího informanta: v ní se zohledňuje ještě další konstitutivní element znaku, totiž tvar ruky:

Když se podívám na znak DRBY/POMLOUVAT, vnímám tam jako důležitý opakovaný pohyb. Tím se odkazuje na důležitou charakteristiku drbů, tedy na jejich putování od jednoho člověka k dalšímu a dalšímu. Tím se vyjadřuje šířeníinformace mezi vícelidí. Důležitý je podle mě také tvar ruky, který jako by zastupoval kapku „informace”, která se rozprskne mezi ostatní lidi do všech stran. A opakovaným pohybem se zdůrazňuje to, že každá tato „kapka”, když se k někomu dostane, pošle ji dál. Zároveň ohnutý ukazováček vnímám jako velmi negativní tvar ruky, který se objevuje ve znacích jako KONCENTRAČNÍ TÁBOR, MUČIT, ale třeba i ve znaku ZLÝ. Podle mě to všechno dohromady skládá negativní význam znaku DRBY/ POMLUVA. Alespoň mi to tak připadá (https://youtu.be/_zyIpZ5ZAXI).

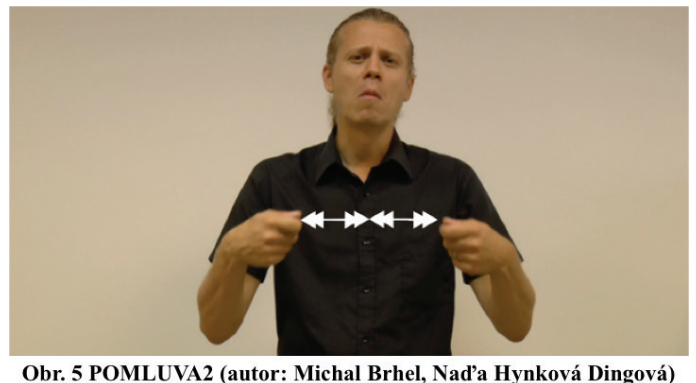

Znak POMLUVA2 (obr. 5), dvouruční symetrický znak artikulovaný zase nikoli u úst, ale $\mathrm{v}$ neutrálním znakovacím prostoru, reflektuje svou formou (vzájemnou polohou rukou a pohybem) blízkost, kontakt, vzájemnost, sdílení - a odkazuje k dialogické, sociální a kulturní dimenzi řeči/komunikace (Vaňková, 2008) ${ }^{19}$. Taková reflexe pomluvy v jazykové formě akcentuje podíl tohoto

18 Rozhovory s českými neslyšícími koncipovala, jejich názory shromáždila a projevy z českého znakového jazyka přeložila N. Hynková Dingová.

19 To nepochybně souvisí s tím, co ve vztahu ke komunikaci znakovými jazyky (a jejich - pořád ještě - nevýraznou funkční diferenciací) doložil Johnston (1996): totiž s dominancí interakční funkce a s relativním potlačením funkce ideační. 
žánru na posilování soudržnosti komunity neslyšících, poukazuje (stejnými tvary rukou a alternativním pohybem) na symetrii sociálních rolí a statutů.

$S$ jistou mírou určitosti lze předpokládat, že znaky POMLUVA1 a POMLUVA2, oba s jiným místem artikulace než ústa, naznačují, do jak značné míry je pomluva neslyšícími přisvojována jako žánr neslyšící komunitě „vlastni””20, jako součást kultury neslyšících; srov.:

Drby jsou v komunitě neslyšících ohromná věc. Pro „národ českých neslyšících” jsou drby, jak bych tak řekl, „koníčkem”. [...] Je to dané tím, že neslyšící jsou v kontaktu, vytvářejí sít kontaktů, a když se v jednom uzlu sítě zaregistruje signál (drb), je vedený jako elektrickým vedením po celé ploše sítě. Bylo to tak vždycky v historii, je to tak dneska a pravděpodobně to tak bude i v budoucnosti. [...] Myslím, že tohle je součástí kultury neslyšících (https://youtu.be/aeDeUN2UYNQ).

K ne malému počtu znaků reflektujících jazyk, řeč/komunikaci se nicméně v českém znakovém přiřazuje místo artikulace ústa - a tuto skutečnost i čeští neslyšící „vidi”” a zvažují:

Přemýšlel jsem o znacích, které se artikulují blízko úst, a přitom souvisí s mluvením nebo jazykem. Je pravda, že takové znaky vycházejí hlavně z mluveného jazyka, z toho, jakým způsobem mluví slyšící lidé. Takových znaků máme v našem jazyce opravdu hodně, za všechny snad alespoň znaky PŘEDNÁŠET, ŘÍCI, VYTKNOUT, ale je jich ve skutečnosti mnohem více. Je zvláštní, že neslyšící používají tyto znaky, znázorňují, jak všechny ty jazykové úkony provádějí slyšící, a přitom tím označují jazykové aktivity neslyšících. Jen se podívejme třeba hned na znak ŘíCI, který začíná u úst jako mluvního orgánu slyšících lidí. Neslyšící by přece neměli sloveso ŘÍCI ve znakovém jazyce a v mluveném jazyce ukazovat úplně stejně. ŘíCI v českém znakovém jazyce bychom měli vyjádřit spíše znakem v neutrálním prostoru. Měli by to tak udělat, ale přesto stále používají znak odkazující na mluvidla. Podobně je to se znakem PŘEDNÁŠKA/PŘEDNÁŠET. Neslyšící k „přednášení” používají především ruce, a přesto ve slovesu PřEDNÁŠET také odkazují na ústa. Opět by se místo artikulace mělo posunout od úst spíše do neutrálního prostoru s odkazem na komunikaci realizovanou primárně pohyby rukou. Já také používám tyto „slyšící znaky" a vlastně jsem nad tím nikdy předtím moc nepřemýšlel. Tyhle znaky pro mě nemají žádný negativní náboj. Ale dneska už nad tím přemýšlím jinak. Uvědomil jsem si, že bychom všechny tyto „slyšící znaky” měli nahradit znaky respektujícími znakový jazyk. Jen mě napadá, jestli jsou tyto změny v našem jazyce reálné. Bude to přinejmenším hodně těžké. Pro starší neslyšící jsou tyto znaky tak automatické, že s nimi asi už nic nebudou chtít dělat. I když zásadní se mi zdá informovanost neslyšících. Když jim někdo řekne, že nemusí slepě používat znaky, které jim nejsou

20 Jen na okraj by možná stálo za to zmínit, jak vypadá znak českého znakového jazyka vytvořený českými neslyšícími pro jiný žánr, komunitou považovaný za „vlastní”, pro ni specifický, totiž znak STORY TELLING: ani v něm nefigurují jako místo artikulace ústa. 
vlastní a mohou si je přetvořit tak, aby více vycházely z jejich jazyka, možná by se to mohlo povést. Kdo ví! Tak to vidím jáa ${ }^{1}$ (https://youtu.be/NgQJj-E8MrI).

I neslyšící Češi tedy reflektují to, co se jeví nám, slyšícím, zatím jen předběžně a na základě omezených dat, dat jazykových. Totiž že jazykový obraz jazyka a řeči /komunikace v českém znakovém jazyce je spjat do jisté míry s ústy, že navzdory jinakosti českého znakového jazyka platí to, co v češtině (Vaňková 2007): i v českém znakovém jazyce stojí za jazyk, řeč/komunikaci (metonymicky?) také ústa. Ústa se v jazykovém obrazu jazyka, řeči a komunikace v českém znakovém jazyce angažují navzdory vyhraněným (a v českém znakovém jazyce i v češtině artikulovaným) názorům českých neslyšících na to, který jazyk je „náš” /,vlastní”, a který „jejich” / „cizí”.

Lingvistika českého znakového jazyka stojí v podobně zaměřených úvahách v podstatě na začátku - někde se ovšem (srov. Popper 1998) začít musí. Časem je samozřejmě možné zaujímat k tomu „počátečnímu”, zde nastíněnému, informovanější postoj: rozšírit získaná data jazyková, doplnit je daty textovými a empirickými - a mj. i na tomto základě příp. nahradit to dosavadní, doposud zvažované, něčím jiným, třeba i poučenějším.

\section{Bibliografie}

Fischer, S.D. (2001). Towards a Typology of Signed Languages. W: B. Palek, O. Fujimura, (red.), Item order: its variety and linguistic and phonetic consequences. Prague: The Karolinum Press, 179-195.

Fónagy, I. (1970). Forma a funkce básnického jazyka. W: Dvanáct esejů o jazyce. Praha: Mladá fronta, 81-123.

Fónagy, I. (1963). Die Metaphern in der Phonetik. The Hague: Mouton \& Company.

Gabrielová, D., Paur, J., Zeman, J. (1998). Slovník znakové řeči. Praha: Horizont.

Hoffmannová, J. (1996). Fatická funkce jazyka, konverzace a její žánry. Slovo a slovesnost, $57,3,91-205$.

Jílek, F. (1967). Vtipná čeština. Praha: Mladá fronta.

Johnston, T. (1996). Function and medium in the forms of linguistic expression found in a sign language. W: W.H. Edmondson - R.H. Wilbur (red.). International Review of Sign Linguistics, vol. 1. Mahwah, NJ: Lawrence Erlbaum, 57-94.

21 Diskuse s neslyšícími uživateli českého znakového jazyka (Znakovárna, komunitní centrum 7.12. 2018) ukázala, že některé znaky s místem artikulace ústa jsou (neuvědoměle? uvědoměle?) nahrazovány (přinejmenším mladší generací neslyšících Čechů) znaky jinými: např. znak MLČET („Ukazovák se položí kolmo na ústa (ticho)”, Gabrielová et. al., 1989, s. 115) se nahrazuje znakem / gestem (?), v němž jsou ruce s dlaněmi orientovanými dozadu přitisknuty k bokům; odkaz na „neaktivitu” manuálních artikulátorů je zde zřejmý. 
Klima, E. - Bellugi, U. (1979). The Signs of Language. Cambridge, Mass.: Harvard University Press.

Lepic, R., Börstell, C., Belsitzman, G., Sandler, W. (2016). Taking Meaning in Hand: Iconic Motivations in Two-handed Signs. Sign Language \& Linguistics, 19 (1), 37-81.

Lotman, J.M. (1994). Text a kultúra. Bratislava: Archa.

McMahon, C. (červen 2016). Sound Culture. Referát přednesený na konferenci „TSID a RID IV Conference 2016". Houston, Texas.

Pokorná, K. (2017) Schéma nádoba v českém znakovém jazyce. W: I. Vaňková, V. Vodrážková, R. Zbořilová (red.). Horizonty kognitivně kulturní lingvistiky. Schémata a stereotypy $v$ mluvených a znakových jazycích. Praha: FF UK, 46-56.

Popper, K. (1998). Život je řešení problémů. O poznání, dějinách a politice. Praha: Mladá fronta.

Potměšil, M. a kol. (2002, 2004). Všeobecný slovník českého znakového jazyka A-N, O-Ž. Praha: Fortuna.

Šebková, H. (2008). Psaná čeština českých neslyšcích v internetové komunikaci. Diplomová práce. Praha: Univerzita Karlova v Praze, Filozofická fakulta.

Šůchová, L. (2007) Metafora v českém znakovém jazyce. Diplomová práce. Praha: Univerzita Karlova v Praze, Filozofická fakulta.

Taub, S. (2001). Language from the Body. Iconicity and Metaphor in American Sign Language. Cambridge, N.Y.: Cambridge University Press.

Vaňková, I. (2007). Nádoba plná řeči (Člověk, řeč a přirozený svět). Praha: Karolinum.

Vaňková, I. (2008). Dobre imię, dobra opinia i oszczerstwo / pomówienie w czeskim obrazie świata. W. R. Grzegorczykowa, K. Waszakowa (red.). Pojęcie, słowo, tekst. Warszawa: Wydawnictwo Uniwersytetu Warszawskiego, 11-26.

Wilbur, R. B. (1990). Metaphors in American Sign Language and English. W: W.H. Edmondson, F. Karlsson, F. (red.). Sign Language Research'87. Hamburg: Signum Press, $163-170$.

Wilcox, P.P. (2000). Metaphors in American Sign Language. Washington, D.C.: Gallaudet University Press.

Woll, B. (1983). The Semantics of British Sign Language Signs. W: J.G. Kyle, B. Woll (red.). Language in Sign: an International Perspective on Sign Language. London\&Canberra: Croom Helm, 40-54.

Zima, J. (1961). Expresivita slova v současné češtině. Studie lexikologická a stylistická. Praha: Nakladatelství ČSAV. 


\title{
ODBICIE JĘZYKA, MOWY I KOMUNIKACJI W CZESKIM JĘZYKU MIGOWYM
}

\author{
(Przekład skróconej wersji artykułu)
}

Punktem wyjścia przedstawionych rozważań jest przekonanie pierwotnie zakotwiczone w lingwistyce kognitywnej lub kognitywno-kulturowej o tym, że „bycie człowiekiem”, „rozumienie” (siebie, innych, świata), „porozumiewanie się” jest nierozerwalnie związane z ludzką umiejętnością posługiwania się językiem / mową, że przez język / mowę człowiek dociera do kultury, do świata - i ów świat, samego siebie wraz z językiem oraz komunikacją interpretuje, czyli przypisuje im znaczenie.

Dotyczy to również człowieka, który nie słyszy. Także osobę niesłyszącą można opisać herderowskim Homo loquens, jako że człowiek niesłyszący też odwzorowuje swój język, swoją mowę /komunikację - czyli uogólniając: w swoim języku (swoim językiem) koduje (mapuje) świat. Omawiane odwzorowanie języka, mowy /komunikacji w czeskim języku migowym (w jego systemie i w wypowiedziach, a w języku czeskim pisanym przez czeskich niesłyszących - realizowanych) jest tu rozważane w różnych kontekstach:

(1) w kontekście specyfiki sytuacji językowej i komunikacyjnej czeskich niesłyszących, ich funkcjonowania $w$ dwóch językach (w naturalnym języku niesłyszącego Czecha, czeskim języku migowym oraz w czeskim języku pisanym jako tym, który towarzyszy procesowi edukacji), w dwóch kulturach, a może nawet w dwóch światach (por. Johnston 1996); czasem jednak „między” dwoma językami, dwiema kulturami, dwoma światami - w żadnym z nich w pełni;

(2) w kontekście innych doświadczeń zmysłowych niesłyszącego człowieka;

(3) w kontekście specyficznych cech języka migowego, z jego odmiennością; jest to język wizualno-motoryczny bez postaci pisanej, charakteryzujący się głównie podwójnymi (manualnymi i niemanualnymi) nośnikami znaczenia, istnieniem w przestrzeni, związaną z tym symultanicznością, a także ikonicznością (czy też tendencją do reprezentacji ikonicznej). W językach migowych przejawia się ona wyraźniej niż w językach mówionych: języki wizualne, osadzone w przestrzeni, są wręcz predysponowane (por. Fischer 2001) do tego, aby świat zorganizowany (czaso)przestrzennie kodować /mapować „przez bezpośrednie imitowanie”, czy też po to, aby w taki sposób kodować /mapować ludzkie, prymarnie wizualne i (czaso)przestrzenne doświadczenie.

Nasuwa się jedak pytanie, czy z tak wyraźną odmiennością języka migowego od języka mówionego / pisanego łączy się także odmienność jego odwzorowania. Rozważane odpowiedzi są (w odniesieniu do ikoniczności języków migowych) skorelowane z rolą tzw. motywacji wizualnej. Wiele znaków ikonicznych wskazuje na swą motywację (i na swe znaczenie) właśnie przez swoją formę, ujmując rzecz inaczej: między konceptem a formą lingwistyczną prowadzona jest wyraźna linia motywacyjna. Analiza motywowanych wizualnie znaków czeskiego języka migowego, które w swej formie w jakiś sposób odwzorowują język, mowę /komunikację (por. Slovník znakové řeči 1988 i Všeobecný slovník českého znakového jazyka 2002, 2004), wskazuje na systemowe środki językowe, które 
biorą udział w owym odwzorowaniu. Jeśli chodzi o środki manualne, są to przede wszystkim elementy konstytutywne znaku, porównywalne $\mathrm{z}$ fonemami (w różnych koncepcjach teoretycznych - por. też aspekty, parametry), zwłaszcza miejsce artykulacji, kształt ręki, ruch.

Z wymienionych elementów konstytutywnych w kontekście odwzorowania języka, mowy/komunikacji najbardziej znaczące staje się jedno miejsce artykulacji - usta. Dowiedziono, że znaki obejmujące to właśnie miejsce artykulacji nie są jednolite pod względem typu: Niektóre z nich (np. MLUVIT 'mówić, ODEZÍRAT 'odczytywać z ruchu warg') jednoznacznie odzwierciedlają produkcję /recepcję wizualną języka mówionego, zaś kolejne (np. ŠEPTAT 'szeptać', MUMLAT 'mamrotać') eksponują parametry artykulacyjne dźwiękowe i fonetyczne języka mówionego. $\mathrm{Z}$ kolei inne znaki z tożsamym miejscem artykulacji (np. ǨÍCT 'powiedzieć', MLČET 'milczeć, PTÁT SE 'pytać się, ODPOVÍDAT 'odpowiadać, LHÁT 'kłamać, MLUVIT PRAVDU 'mówić prawdę') odwzorowują język, mowę /komunikację powiązaną ze sposobem komunikacji mówiącej większości, na przekór temu, że czeski niesłyszący człowiek pyta się, odpowiada, kłamie lub mówi prawdę w czeskim języku migowym.

Ten fakt jest następnie konfrontowany $\mathrm{z}$ eksplicytnie formułowanymi opiniami czeskich niesłyszących na temat czeskiego języka migowego (języka, który jest „nasz”, „własny”) i na temat języka czeskiego (języka „ich”, „obcego”) - i omawiany w kontekście tematyzacji tego faktu (por. McMahon 2016), konkretnie z zaleceniem używania zamiast znaków amerykańskiego języka migowego (z ustami jako miejscem artykulacji) znaków artykułowanych w innym miejscu. Znaki odzwierciedlające język, mowę /komunikację i nieartykułowane przy ustach oczywiście istnieją również w czeskim języku migowym - opisane zostały dwa znaki z czeskim ekwiwalentem 'plotka' - POMLUVA 'plotka' 1 i POMLUVA 'plotka' 2: jeden niesie negatywne, drugi pozytywne konotacje.

Jednakże do znaczącej części znaków czeskiego języka migowego odwzorowujących język, mowę /komunikację jako miejsce artykulacji przyporządkowane są usta - i fakt ten „widzą" i uwzględniają również czescy niesłyszący: także niesłyszący Czesi odwzorowują (jak zostało tu dowiedzione na razie tylko wstępnie i na podstawie ograniczonych danych językowych) to, co widoczne jest dla nas, słyszących. Zatem również językowy obraz „mowy” w czeskim języku migowym jest do pewnego stopnia związany z ustami, czyli na przekór odmienności czeskiego języka migowego od języka fonicznego obrazy te w obydwu językach są pod tym względem podobne (por. Vaňková 2007), bo w obydwu, także w czeskim języku migowym (metonimicznie?), za język, mowę/komunikację odpowiadają (też) usta. Usta w językowym obrazie języka, mowy i komunikacji w czeskim języku migowym pojawiają się na przekór dobitnym (wyrażanym w czeskim języku migowym i w pisanej czeszczyźnie) opiniom czeskich niesłyszących o tym, który język jest „nasz” /,własny”, a który „ich” /,obcy”. 